\title{
Problems of pricing in the field of maintenance and operation of urban areas and the ways to solve them on the example of the Sochi city
}

\author{
Aleksandr Sekisov ${ }^{1 *}$, Marina Kovtunenko ${ }^{2}$, Irina Fokina ${ }^{2}$, Ishkhan Zakaryan ${ }^{2}$, and Sergei \\ Pastukhov ${ }^{2}$ \\ ${ }^{1}$ Kuban State Agrarian University named after I.T. Trubilin, 350004, Krasnodar, Russian Federation \\ ${ }^{2}$ Kuban State Technological University, 350072, Krasnodar, Russian Federation
}

\begin{abstract}
The resort town Sochi is a municipality on the territory of Russia in the Krasnodar Krai. The location in the mountainous area and the proximity to the sea makes the Sochi city special in terms of the variety of possibilities for the resort services provision. In addition to a beach holiday on the Black Sea coast, Sochi is a place of attraction for the lovers of outdoor activities in the mountains: alpine skiing, snowboarding, mountain biking, and tourism. Historically, the city of Sochi is an all-Russian health resort, because in addition to favorable climatic conditions and the proximity of the sea, there are unique sources of mineral water and the balneological resort Matsesta, where tourists from all over the country and from abroad come for treatment all year round. More details about the current state of the region, plans and development prospects are presented in the scientific works $[1-4,5-7]$.
\end{abstract}

\section{Introduction}

Taking into account the popularity of the resort city of Sochi for tourism and recreation, special attention must be paid to maintaining the state of urban areas, parks, squares, to maintain the existing image of the resort city. Maintenance of municipal territories, which include city parks, squares, roads, is carried out at the budget expense in Sochi.

\section{Main part}

\subsection{Methods and materials}

The analysis of the price situation in the region was carried out using the official website of the unified procurement information system www.zakupki.gov.ru. Scientific articles on the topic "Pricing in construction", educational and reference manuals [1-4, 8-12] were used as a theoretical basis for the study. Estimated standards were monitored using the capabilities

\footnotetext{
*Corresponding author: alnikkss@gmail.com
} 
of the "Grand-Smeta" software package, as well as by referring to the official websites of standards developers.

\subsection{Discussion}

The team of authors analyzed the municipal contracts concluded in 2020 for the maintenance of public areas in the Sochi districts according to the data. The cost of some types of work is shown in Table 1 in the form of a comparative analysis.

A visual analysis of the data in the table shows a colossal difference in the cost of one type of work for different contractors. The conclusion of a contract is possible both with a single supplier and through an electronic bidding procedure.

In the studied contracts (Table 1), as a justification for the initial maximum price of the contract:

- market price analysis;

- individual cost estimates;

- estimated standards and individual cost estimates.

In this case, a small price range can be assumed. But the difference that is visible in the list under study is very difficult to name. The question arises, how is it possible, within the same municipal district, to have such a different cost of the same types of work?

The cost of work (service) consists of several components: the wage fund for maintenance personnel, the cost of consumables, the operation of machines and mechanisms, inventory, overhead costs, and estimated profit.

The Industry Tariff Agreement was approved by the Ministry of FES and HUI of the Krasnodar Krai to determine the wage fund for personnel employed in the field of housing and communal services [13].

Table 1. Comparative analysis of the cost indicators for the certain types of work on the maintenance of urban areas in Sochi

\begin{tabular}{|c|c|c|c|c|c|c|}
\hline \multirow{4}{*}{ Work } & \multirow{4}{*}{ Unit } & \multicolumn{5}{|c|}{ Service cost in Sochi districts } \\
\hline & & \multicolumn{2}{|c|}{ Central } & Adler & Khostinsky & $\begin{array}{l}\text { Sirius } \\
\text { village }\end{array}$ \\
\hline & & $\begin{array}{c}\text { Contra } \\
\text { ct EA } \\
01 / 58 \\
2 \text { from } \\
08.10 . \\
2018\end{array}$ & $\begin{array}{c}\text { Contract EA } \\
03 / 87 \text { from } \\
30.03 .2020\end{array}$ & $\begin{array}{c}\text { Contract } \\
842 \\
\text { from } \\
29.12 .2020\end{array}$ & $\begin{array}{c}\text { Contract } \\
0118300018 \\
719000905 \\
\text { from } \\
27.01 .2020\end{array}$ & $\begin{array}{c}\text { Contract } \\
38 / 2020 \\
\text { from } \\
05.08 .2020\end{array}$ \\
\hline & & \multicolumn{2}{|c|}{ LLC "Eco- Service" } & $\begin{array}{c}\text { IE } \\
\text { Kudryavtse } \\
\text { v }\end{array}$ & $\begin{array}{c}\text { LLC } \\
\text { "Blagoustroi } \\
\text { stvo" }\end{array}$ & $\begin{array}{c}\text { GF "Talent } \\
\text { and } \\
\text { Success" }\end{array}$ \\
\hline $\begin{array}{l}\text { Collecting } \\
\text { random } \\
\text { rubbish on } \\
\text { sidewalks, } \\
\text { stairs, under } \\
\text { benches }\end{array}$ & $100 \mathrm{~m}^{2}$ & 383.24 & 323.80 & 13.12 & 11.28 & 46.58 \\
\hline $\begin{array}{l}\text { Cleaning } \\
\text { lawns from } \\
\text { debris }\end{array}$ & $100 \mathrm{~m}^{2}$ & 330.25 & 273.65 & 10.10 & 260.00 & 10.80 \\
\hline $\begin{array}{l}\text { Manual } \\
\text { cleaning of } \\
\text { bins over } 10 \\
\text { liters }\end{array}$ & pc. & 20.70 & 19.00 & 8.92 & 24.21 & 42.82 \\
\hline
\end{tabular}




\begin{tabular}{|l|l|l|l|l|l|l|}
\hline $\begin{array}{l}\text { Combined } \\
\text { lawn } \\
\text { mowing }\end{array}$ & $100 \mathrm{~m} 2$ & 341.60 & 279.31 & 234.78 & 247.00 & 511.40 \\
\hline
\end{tabular}

Since the organizations' activities are carried out within the boundaries of one municipal district, the resources cost (materials, mechanisms) to ensure the process of performing work should not have significant differences. In this regard, the conclusion suggests itself that the difference in the total cost of performing work is due to differences in the definition of labor intensity.

In order to understand the situation, it was decided to conduct a study of the current estimated standards using the example of the types of work presented in Table 1. The purpose of the study is to study the possibilities of the estimate and regulatory framework, if necessary, to determine the work price, the prices for which absent in the estimated standards: state itemized cost estimate standards, federal unit rates, territorial unit costs; calculate the cost of providing services and compare with the indicators in Table 1.

\section{Research and results}

Since there are no developed and approved unit prices for this type of work for the Krasnodar Krai, the choice of prices is carried out within the entire available estimate and regulatory base, including state elementary estimates (state itemized cost estimate standards), industry, company standards, territorial base of Moscow (Moscow territorial costing standards). After a selection of prices corresponding to the type of work, it is required to compare them with each other and analyze the possibility of using them in a particular case. In the study [14], the systematization of estimated standards for work on the maintenance and service of the facilities was carried out. Using the data of the article [14], it is possible to search for suitable prices from the proposed list. In the course of the search, it was revealed that the prices for works similar to those sought are contained in the collections: proprietary estimated standards Municipal economy: "Your house", "Our city. Road facilities"; Service standards for the workers engaged in sanitary maintenance of households (SS); regulatory and production regulations for the maintenance of urban green spaces (FAT 1987) [15-17].

To calculate the unit cost, it is necessary to determine the basic salary of area cleaning workers and green workers. The minimum wage in the Krasnodar Krai must be no less than the subsistence minimum for the able-bodied population, i.e., 11,675 rubles per month (Q1 2020). The procedure for calculating wages is defined in the Industry Tariff Agreement (art.3.10.2). One of the initial data for determining the wage rate of a worker is the number of working hours per month. This indicator is calculated based on the standard for the working week duration - 40 people / hour. According to the production calendar for 2020 , with a 40-hour work week, the number of working hours per year is 1979; per month $1979 / 12=164.92$. Calculation of the minimum wage rate for a territory cleaner (taking into account compensation payments $12.5 \%$, seniority remuneration $15 \%$, monthly bonuses 40\%): $11675 \times 1,125 \times 1,15 \times 1,40 / 164,92=128,22 \mathrm{rub} /$ hour. In accordance with the standards, a green farm worker has a tariffing by category. Tariff coefficients are established by the Industry Tariff Agreement. The amount of overhead costs and the estimated profit of the organization providing services for the maintenance of facilities must be determined independently, taking into account the specifics of the work. The definition of standards is regulated by the Order of the Ministry of Construction, Housing and Utilities of the Russian Federation dated November 28, 2017 No. 1596/pr [18]. In accordance with the provisions of the Order, in the absence of approved norms for overhead costs and profitability, the calculation of values is made on the basis of actual indicators for the past period or by 
calculating the median value for government organizations that provide these types of services.

The search for the developed standards for the service sector of urban areas of the city of Sochi did not give any results. Overhead costs are accepted by the authors in the amount of $95.2 \%$ of salary fund (composed of: $30.2 \%$ - deductions for social needs of workers; $65 \%$ - general operating costs); estimated profit $-10 \%$ of direct costs. In the process of searching for a quote, one should be guided by a set of factors: the legitimacy of the collection; the possibility of applying these standards in a specific case, in accordance with the technical part; the correspondence of the work-bot rates composition to the required type of work; total cost. As a result of the listed factors' combination analysis the final price selection is made (Table 2)

Table 2. The choice of prices and the work cost calculation according to collections

\begin{tabular}{|c|c|c|c|c|c|c|c|}
\hline \multicolumn{2}{|c|}{$\begin{array}{l}\text { Collecting random } \\
\text { garbage on sidewalks, } \\
\text { stairs, under benches, } \\
\text { units rev. } 100 \mathrm{~m} 2 \\
\text { (excluding VAT) }\end{array}$} & \multicolumn{2}{|c|}{$\begin{array}{c}\text { Cleaning lawns from } \\
\text { debris, } \\
\text { units } 100 \mathrm{M} 2 \\
\text { (excluding VAT) }\end{array}$} & \multicolumn{2}{|c|}{$\begin{array}{c}\text { Manual cleaning of } \\
\text { trash cans over } 10 \\
\text { liters, } \\
\text { unit of measure } 1 \\
\text { piece (excluding VAT) }\end{array}$} & \multicolumn{2}{|c|}{$\begin{array}{c}\text { Mowing } \\
\text { combined lawns, } \\
\text { unit } 100 \mathrm{~m} 2 \text { (excluding } \\
\text { VAT) }\end{array}$} \\
\hline Pricing & $\begin{array}{c}\text { Price, } \\
\text { rub. }\end{array}$ & Pricing & $\begin{array}{c}\text { Price, } \\
\text { rub. }\end{array}$ & Pricing & $\begin{array}{c}\text { Price, } \\
\text { rub. }\end{array}$ & Pricing & $\begin{array}{c}\text { Price, } \\
\text { rub. }\end{array}$ \\
\hline $\begin{array}{l}\text { D_1-02-01- } \\
012 \\
\text { Cleaning } \\
\text { the territory } \\
\text { from } \\
\text { accidental } \\
\text { garbage }\end{array}$ & 35.79 & $\begin{array}{l}\text { SS-1-17- } \\
1 \\
\text { Cleaning } \\
\text { lawns } \\
\text { from } \\
\text { accident- } \\
\text { tal debris }\end{array}$ & 36.50 & $\begin{array}{l}\text { SS-1-26-1 } \\
\text { Cleaning of } \\
\text { trash bins, } \\
\text { types of } \\
\text { bins: cast } \\
\text { iron } \\
\text { (diameter - } \\
200-300 \\
\text { mm, height } \\
-650 \mathrm{~mm} \text { ) }\end{array}$ & 22.31 & $\begin{array}{l}\text { Z 02-109-001 } \\
\text { Mowing a } \\
\text { continuous } \\
\text { lawn with a } \\
\text { lawn mower } \\
\text { KR-0,75 } \\
\text { Z 02-109-012 } \\
\text { Raking cut } \\
\text { grass when } \\
\text { mowing with } \\
\text { a lawn mower }\end{array}$ & 137.16 \\
\hline $\begin{array}{l}\text { SS-1-25-3- } \\
\text { б Cleaning } \\
\text { of areas of } \\
\text { territories } \\
\text { from } \\
\text { garbage } \\
\text { during } \\
\text { mechanized } \\
\text { cleaning: } \\
\text { territory of } \\
\text { the 3rd } \\
\text { class }\end{array}$ & 49.39 & $\begin{array}{l}\text { VD-3-02- } \\
\text { 03-01 } \\
\text { Removin } \\
\text { g rubbish } \\
\text { from } \\
\text { lawns } \\
\text { with } \\
\text { medium } \\
\text { weedines } \\
\text { s }\end{array}$ & 321.20 & $\begin{array}{l}\text { VD }(2.1)-3- \\
02-03-06 \\
\text { Cleaning } \\
\text { trash cans }\end{array}$ & 21.88 & $\begin{array}{l}\text { VD (2.1)-3- } \\
\text { 02-03-05 } \\
\text { Lawn } \\
\text { mowing }\end{array}$ & 341.79 \\
\hline $\begin{array}{l}\text { SS-1-19-1-e } \\
\text { Sweeping } \\
\text { areas with } \\
\text { improved } \\
\text { coverage: } \\
\text { area } 3 \text { class }\end{array}$ & 68.71 & $\begin{array}{l}\text { FAT } \\
1.2 .1-16- \\
3 \\
\text { Cleaning } \\
\text { lawns } \\
\text { from } \\
\text { accident- } \\
\text { tal debris } \\
\text { with } \\
\text { removal } \\
\text { outside } \\
\text { the lawn }\end{array}$ & 8.27 & $\begin{array}{l}\text { FAT 1.2.8- } \\
\text { 5a-22 } \\
\text { Cleaning } \\
\text { trash cans } \\
\text { with } \\
\text { garbage } \\
\text { disposal } \\
\text { and carry }\end{array}$ & 21.88 & $\begin{array}{l}\text { State itemized } \\
\text { cost estimate } \\
\text { standards } \\
\text { p68-4-2 } \\
\text { Mowing } \\
\text { lawns: with a } \\
\text { lawn mower }\end{array}$ & 322.36 \\
\hline $\begin{array}{l}\text { VD-3-02- } \\
01-03 \\
\text { Summer } \\
\text { sweeping of } \\
\text { a land plot } \\
\text { with }\end{array}$ & 55.06 & & & $\begin{array}{l}\text { D1-04-04- } \\
\text { 004 } \\
\text { Cleaning } \\
\text { trash cans }\end{array}$ & 22.31 & $\begin{array}{l}\text { FAT 2.2.4-1b } \\
\text { Mowing an } \\
\text { ordinary lawn } \\
\text { FAT 1.2.1- } \\
\text { 11-32 Raking } \\
\text { and cleaning }\end{array}$ & 363.10 \\
\hline
\end{tabular}




\begin{tabular}{|c|c|c|c|c|c|c|c|}
\hline $\begin{array}{l}\text { improved } \\
\text { coverage of } \\
\text { the 3rd } \\
\text { class }\end{array}$ & & & & & & $\begin{array}{l}\text { of cut grass } \\
\text { with a nose- } \\
\text { nose and } \\
\text { stacking in } \\
\text { heaps }\end{array}$ & \\
\hline $\begin{array}{l}\text { FAT 1.2.8 } \\
\text { art.7a } \\
\text { Sweeping } \\
\text { asphalt } \\
\text { paths and } \\
\text { collecting } \\
\text { debris in } \\
\text { heaps }\end{array}$ & 63.32 & & & & & & \\
\hline \multicolumn{8}{|c|}{ Price selection } \\
\hline $\begin{array}{l}\text { D_1-02-01- } \\
012 \\
\text { Cleaning } \\
\text { the territory } \\
\text { from } \\
\text { accidental } \\
\text { garbage }\end{array}$ & 35.79 & $\begin{array}{l}\text { FAT } \\
1.2 .1-1 b- \\
3 \\
\text { Cleaning } \\
\text { lawns } \\
\text { from } \\
\text { accidenta } \\
1 \text { debris } \\
\text { with } \\
\text { removal } \\
\text { outside } \\
\text { the lawn }\end{array}$ & 8.27 & $\begin{array}{l}\text { FAT 1.2.8- } \\
\text { 5a-22 } \\
\text { Cleaning } \\
\text { trash cans } \\
\text { with } \\
\text { garbage } \\
\text { disposal } \\
\text { and carry }\end{array}$ & 21.88 & $\begin{array}{l}\text { State itemized } \\
\text { cost estimate } \\
\text { standards } \\
\text { p68-4-2 Lawn } \\
\text { mowing: } \\
\text { lawn mowing }\end{array}$ & 322.36 \\
\hline $\begin{array}{l}\text { Total, } \\
\text { rubles } \\
\text { including } \\
\text { VAT } 20 \%\end{array}$ & 42.95 & & 9.92 & & 26.26 & & 386.83 \\
\hline
\end{tabular}

\section{Conclusion}

This study showed that if it is necessary to plan the costs of these types of work, a problem, consisting in the absence of uniform standards for the performance of work on the maintenance of urban areas for the city of Sochi (and the Krasnodar Krai), arises. The current situation leads to the fact that the contractor forms the cost in the most convenient way for him and when comparing the prices of different contractors, there is a wide variation.

It is possible to implement a solution to the problem in the following ways:

1. Selection of a suitable standard by referring to the existing, developed, standards individually for each type of work (by analogy with the method carried out in the study), based on the regulatory literature. This method has its drawbacks: it involves the use of industry and departmental standards developed for a specific field of activity or object affiliation. For example, in this study, the standards were applied to service the territory of apartment buildings and objects of the city road and green economy. Parks and squares belong to the objects of green economy; however, the proposed collection of standards does not contain works on garbage collection and cleaning of trash cans, which, in turn, are included in the standards of collections for servicing residential buildings. The inconsistency of the scope of application makes the application of the standards incorrect. Another issue when using industry standards will be to determine the amount of overhead costs: there are no regulated standards, the organization will need to calculate them independently. For these reasons, the pricing method cannot be called accurate and reliable.

2. Development of standards for the entire list of works on the maintenance of urban areas. In this case, we are talking about a long process of standardization of work (throughout the year), which consists in monitoring the progress of implementation, fixing 
the time (photo timing) for the implementation of the volume of each type of work, accounting for the consumption of materials, tools, and the operating time of special equipment. All observations are documented, regulations are formed, which will become the methodological basis for the future norms development. The regulatory framework formed in this way will take into account the specifics of the facility, the features and complexity of work in a given region, using modern technical and material means. This method is the most accurate for further use in regional organizations and is flexible, since in the event of new technical capabilities, the standards can be adjusted.

3. Calculation of the unit cost for each type of work. The calculation assumes a method for analyzing and comparing prices for similar work among municipal organizations in the region that carry out the activities for the urban areas' maintenance. At the same time, this method does not imply the derivation of the average price indicator, but requires an economic analysis of the economic activities of organizations throughout the calendar year, in order to assess the actual costs. The result of this work will be the determination of tariffs (unit cost prices) for each type of work with the possibility of further indexing for future periods of time, taking into account the inflation level in the region. This method takes into account the prevailing practice in the region and relies on data on the actual resources expended. The cost indicators calculated in this way reliably reflect the economic situation in the region.

The methods of solving the problem proposed in art. 2 and 3 require a long process of observation, a detailed analysis of the current situation. The result of these developments implementation will be a formed, economically justified, regulatory framework for subsequent long-term use in the field of maintenance and service of urban areas.

\section{References}

1. N.A. Shipilova, A.A. Savenko, A.A. Shikhovtsov, A.N. Sekisov, R.A. Popov, G.V. Mikheev, International Journal of Applied Business and Economic Research, Serials Publications, India 15 (23), 173-183 (2017). (Access mode: https://serialsjournals.com/abstract/37837_16_natalia.pdf).

2. G.V. Mikheev, A.N. Sekisov, D.A. Gura, A.G. Abazyan, O.A. Kuznetsova, Revista Inclusiones, Chile 6 (2), 119-124 (2019). (Access mode: http://www.archivosrevistainclusiones.com/gallery/9\%20vol\%206\%20num\%202\%202 019abriljunioasiaeuropaasia19incl.pdf).

3. E.V. Solovyova, A.N. Sekisov, D.A. Gura, G.V. Mikheev, M.G. Kovtunenko, Helix, Singapore, 10 (2), 63-71 (2020). (Access mode: http://helixscientific.pub/index.php/Home/article/view/112/112, https://doi.org/10.29042/2020-10-2-63-71).

4. S. Ovchinnikova, A. Sekisov, I. Shinkareva, E. Schneider, E. Tamoshkina. Implementation of investment and construction projects as part of the interior image formation, XIII International Scientific Conference Architecture and Construction 2020. IOP Publishing. IOP Conf. Series: Materials Science and Engineering 953 (2020). Access mode: https://iopscience.iop.org/article/10.1088/1757899X/953/1/012082/pdf. doi:10.1088/1757-899X/953/1/012082).

5. M.A. Aslanova, The current state and prospects of tourism development in the resort city of Sochi, Problems and prospects of socio-economic development of the regions of the South of Russia: collection of scientific papers based on the materials of the IV AllRussian scientific and practical conference, p. 90-94 (2018).

6. Yu.I. Draisis, Bulletin of the Academy of Knowledge 29(6), 131-139 (2018). 
7. A.V. Iskrina, O.S. Pokhodenko, Post Olympic legacy of the Winter Olympic Games in the history of modern Russia, Olympic legacy and large-scale events: impact on the economy, ecology and socio-cultural sphere of host destinations: collection of scientific papers based on the materials of the XI International scientific-practical Conference, Sochi, November 14-15 Sochi, SSU, Pp.123-126 (2019).

8. V.D. Ardzinov, N.I. Baranovskaya, A.I. Kurochkin, Estimated business in construction. Self-teacher. 4th ed., Revised and enlarged (Peter, SPb., 2017).

9. G.I. Devyatko, E.E. Danilenko, I.V. Anenkova, N.D. Natroshvili, Reference and methodological manual for the builder estimator, Sochi: LLC «Gooks decor», 2005.

10. M.G. Kovtunenko, V.V. Zavorotynskaya, Bulletin of magistracy 12-4 (87), 166-169 (2018).

11. A.S. Garanyan, M.G. Kovtunenko, Trends in the science and education development, 45-2, 28-31 (2018).

12. M.V. Ilyina, O.A. Mamaeva, A.Yu. Bocharov, E.A. Bashkirova, Bulletin of the Samara Municipal Institute of Management 2, 37-47 (2019).

13. Sectoral tariff agreement in the housing and communal services, fuel and energy complex and the service sector of the Krasnodar Krai for 2020-2022.

14. I.G. Fokina, M.G. Kovtunenko, A.V. Dolbyshev, M.N. Romashina, V.V. Derkach, Bulletin of Eurasian Science 6 (2020). Access mode: https://esj.today/PDF/01SAVN620.pdf).

15. Firm estimated standards "Your house", "Our city. Road facilities" developed by CJSC "Center for Municipal Economics and Law".

16. Service standards for workers engaged in sanitary maintenance of households were developed by the State Scientific and Technical Center for Rationing and Information Systems in Housing and Communal Services of the Ministry of Construction of Russia and the Central Bureau of Labor Standards of the Ministry of Labor of the Russian Federation and approved by the Resolution of the Ministry Labor of the Russian Federation of June 24, 1996. No 38 (current).

17. Normative production regulations for the maintenance of urban green spaces were developed in order to regulate the maintenance of green spaces and elements of the well-being of landscaping objects, use it in the development of an economic feasibility study for the production plan for the performance of work, as well as in determining the needs for labor, materials, machines mechanisms. Approved by the Order of the Gosstroy of Russia dated December 10, 1999 No. 145 (current).

18. General requirements for the determination of standard costs for the provision of state (municipal) services in the field of housing and communal services, landscaping, townbuilding activities, construction and architecture, used in calculating the amount of subsidies for financial support for the fulfillment of the state (municipal) task for provision of state (municipal) services (performance of work) by a state (municipal) institution (approved by the Order of the Ministry of Construction, Housing and Utilities of the Russian Federation dated November 28, 2017 No. 1596/pr). 